\title{
PENGARUH SUKU BUNGA, INFLASI DAN NILAI TUKAR RUPIAH TERHADAP HARGA SAHAM DI SEKTOR TELEKOMUNIKASI YANG TERCATAT DI BURSA EFEK INDONESIA PERIODE 2015-2020
}

\author{
${ }^{1 *}$ Reza Octovian, ${ }^{2}$ Dijan Mardiati \\ Universitas Pamulang, Tangerang Selatan, Banten, Indonesia \\ 1*dosen01431@unpam.ac.id, 22dosen011464@unpam.ac.id
}

\begin{abstract}
Abstrak
Tujuan penelitian ini adalah untuk mengetahui pengaruh Pengaruh Suku Bunga, Inflasi, Nilai Tukar Rupiah Terhadap Harga Saham Di Sektor Telekomunikasi Yang Tercatat Di Bursa Efek Indonesia Periode 2015 - 2020. Jumlah sampel yang digunakan sebanyak 24 sampel dari 4 perusahaan telekomunikasi selama kurun waktu 6 tahun. Penelitian ini menggunakan data kuantitatif, metode yang digunakan dalam penelitian ini mengunakan analisis dekripsi data statistik dan menggunakan uji asumsi klasik yaitu uji normalitas, uji multikolinieritas, uji autokolerasi, uji heteroskedastisitas serta menggunakan analisis regresi linier berganda, uji kelayakan model yaitu dengan uji-t, uji-f serta koefiesien determinasi. Dalam menganalisis data penelitian ini menggunakan alat bantu program SPSS versi 28. Dari hasil penelitian secara parsial terhadap harga saham 4 (empat) perusahaan telekomunikasi yang terdaftar di bursa Efek indonesia periode 2015-2020 diperoleh informasi bahwa Suku Bunga tidak berpengaruh terhadap harga saham telekomunikasi, Inflasi berpengaruh kurang signifikan terhadap harga saham telekomunikasi dan nilai tukar berpengaruh cukup signifikan terhadap harga saham telekomunikasi. Sedangkan hasil uji secara simultan antara suku bunga, inflasi dan nilai tukar menunjukkan terdapat pengaruh yang signifikan dengan harga saham telekomunikasi yang terdaftar di BEI selama kurun waktu 2015 - 2020.
\end{abstract}

Kata Kunci: Suku Bunga, Inflasi, Nilai Tukar Rupiah dan Harga Saham

\section{Abstract}

The purpose of this study was to determine the effect of interest rates, inflation, and rupiah exchange rates on stock prices in the telecommunications sector listed on the Indonesia Stock Exchange for the 2015-2020 period. The number of samples used were 24 samples from 4 telecommunications companies over a period of 6 years. This study uses quantitative data, the method used in this study uses statistical data decryption analysis and uses the classical assumption test, namely normality test, multicollinearity test, autocorrelation test, heteroscedasticity test and using multiple linear regression analysis, model feasibility test, namely by $t$-test, $f$-test and coefficient of determination. In analyzing this research data using the SPSS version 28 program tool. From the results of a partial study of the stock prices of 4 (four) telecommunication companies listed on the Indonesia Stock Exchange for the 2015-2020 period, information was obtained that interest rates have no effect on telecommunications stock prices, inflation has a less significant effect on telecommunications stock prices and the exchange rate has a significant effect on telecommunications stock prices. Meanwhile, the results of the simultaneous test between interest rates, inflation and exchange rates show that there is a significant effect on telecommunications stock prices listed on the IDX during the period 2015 2020.

Keywords: Interest Rate, Inflation, Rupiah Exchange Rate and Stock Price

\section{PENDAHULUAN}

Dalam perekonomian suatu Negara, pasar modal memiliki peran besar yang dapat menjadi alternatif sumber pembiayaan kegiatan perusahaan. Sumber pembiayaan tersebut dapat melalui penjualan saham maupun penerbitan obligasi oleh perusahaan yang membutuhkan dana. Pasar modal merupakan salah satu alternatif pilihan investasi yang dapat menghasilkan tingkat keuntungan optimal bagi investor (Hismedi dkk, 2013). Selain itu, pasar modal juga merupakan suatu usaha penghimpunan dana masyarakat secara langsung dengan cara menanamkan dana ke dalam perusahaan yang sehat dan baik pengelolaannya. Fungsi utama pasar modal adalah sebagai sarana pembentukan modal dan akumulasi dana bagi pembiayaan suatu perusahaan atau emiten. Dengan demikian pasar modal 
merupakan salah satu sumber dana bagi pembiayaan pembangunan nasional pada umumnya dan emiten pada khususnya di luar sumber-sumber yang umum dikenal, seperti tabungan pemerintah, tabungan masyarakat, kredit perbankan dan bantuan luar negeri.

Berdasarkan faktanya pemerintah sekarang harus berhadapan dengan kenyataan perlambatan ekonomi global yang dapat mempengaruhi investasi. Faktor utama yang menyebabkan harga pasar saham berubah adalah adanya persepsi yang berbeda dari masing-masing investor sesuai informasi yang dimiliki. Faktor fundamental makro ekonomi yaitu inflasi, tingkat bunga, kurs dan pertumbuhan ekonomi merupakan faktor-faktor yang sangat diperhatikan oleh para pelaku pasar bursa (Bramantio dkk, 2013). Perubahan-perubahan yang terjadi pada faktor ini dapat mengakibatkan perubahan-perubahan di pasar modal, yaitu meningkat atau menurunnya harga saham.

Di Indonesia kebijakan tingkat suku bunga dikendalikan secara langsung oleh Bank Indonesia melalui BI rate (Witjaksono, 2010). BI rate merupakan respon bank sentral terhadap tekanan inflasi ke depan agar tetap berada pada sasaran yang telah ditetapkan. Perubahan BI rate sendiri dapat memicu pergerakan di pasar saham Indonesia. Penurunan BI rate secara otomatis akan memicu penurunan tingkat suku bunga kredit maupun deposito.

Demikian pula halnya dengan inflasi, tingkat inflasi yang tinggi biasanya dikaitkan dengan kondisi ekonomi yang terlalu panas (overheated). Artinya, kondisi ekonomi mengalami permintaan atas produk yang melebihi kapasitas penawaran produknya, sehingga harga-harga cenderung mengalami kenaikan. Inflasi yang terlalu tinggi juga akan menyebabkan penurunan daya beli uang (Purchasing Power of Money). Disamping itu, inflasi yang tinggi juga bisa mengurangi tingkat pendapatan riil yang diperoleh investor dari investasinya. Permana dan Sularto (2008:1) mengemukakan bahwa "faktor yang dapat mempengaruhi ekspektasi harga saham yang biasanya dipertimbangkan oleh investor yaitu adalah kinerja fundamental keuangan perusahaan untuk menghasilkan laba, pergerakan suku bunga bank, tingkat inflasi, kurs nilai tukar mata uang, serta kondisi sosial politik suatu negara”. Efni (2009:1) mengemukakan bahwa "faktor yang mempengaruhi harga saham adalah faktor fundamental seperti, kemampuan manajemen, prospek perusahaan, prospek pemasaran, perkembangan teknologi, kemampuan menghasilkan keuntungan, manfaat terhadap perekonomian nasional, kebijakan pemerintah dan hak-hak investor".

Selain inflasi, variabel lain adalah nilai tukar (kurs). Nilai tukar mencerminkan keseimbangan permintaan dan penawaran terhadap mata uang dalam negeri maupun mata uang asing USD. Merosotnya nilai tukar rupiah merefleksikan menurunnya permintaan masyarakat internasional terhadap mata uang rupiah karena menurunnya peran perekonomian nasional atau karena meningkatnya permintaan mata uang asing USD oleh masyarakat karena perannya sebagai alat pembayaran internasional. Kenaikan harga valuta asing disebut depresiasi atas mata uang dalam negeri. Mata uang asing menjadi lebih mahal, ini berarti nilai relatif mata uang dalam negeri merosot. Turunnya harga valuta asing disebut apresiasi mata uang dalam negeri. Mata uang asing menjadi lebih murah, ini berarti nilai relatif mata uang dalam negeri meningkat. Perubahan nilai tukar valuta asing disebabkan karena adanya perubahan permintaan atau penawaran dalam bursa valuta asing (hukum penawaran dan permintaan). Banyak sebab yang melatarbelakangi perubahan ini seperti, neraca ekspor impor, aliran modal, perubahan struktur, neraca perdagangan dan lain-lain.

Penelitian yang dilakukan Rossy (2018) menunjukkan hasil bahwa nilai tukar (kurs) rupiah dan tingkat inflasi memiliki pengaruh negatif dan signifikan terhadap harga saham pada Sub-Sektor Perbankan BEI. Penelitian yang dilakukan Rohanda dkk (2014) menunjukkan hasil bahwa kurs rupiah berpengaruh terhadap harga saham pada masing-masing Indeks Sektoral BEI dengan arah hubungan negatif. Inflasi tidak berpengaruh terhadap harga saham pada masing-masing Indeks Sektoral BEI. Sementara BI rate hanya berpengaruh terhadap harga saham di enam sektor, yaitu Indeks Sektor Properti dan Real Estate, Indeks Sektor Aneka Industri, Indeks Sektor 
Manufaktur, Indeks Sektor Perdagangan Jasa dan Investasi, Indeks Sektor Pertambangan serta Indeks Sektor Keuangan.

Penelitian yang dilakukan Topowijono dkk (2016) menunjukkan hasil bahwa BI rate dan inflasi tidak terdapat pengaruh yang signifikan secara parsial terhadap harga saham. Sedangkan nilai tukar terdapat pengaruh yang signifikan secara parsial terhadap harga saham pada Sub-Sektor Perbankan BEI.

\section{TINJAUAN \\ PUSTAKA}

\section{Suku Bunga}

Suku bunga atau Bank Indonesia Rate adalah suku bunga kebijakan yang mencerminkan sikap atau stance kebijakan moneter yang ditetapkan oleh Bank Indonesia dan diumumkan kepada publik. Sejak tanggal 19 Agustus 2016, resmi diumumkan dalam laman website Bank Indonesia, bahwa suku bunga acuan yang digunakan sekarang adalah BI 7-day (Reverse) Repo Rate. Sebelum periode tersebut, suku bunga acuan menggunakan BI rate.Suku bunga atau Bank Indonesia Rate diumukan oleh Dewan Gubernur Bank Indonesia setiap Rapat Dewan Gubernur bulanan dan diimplementasikan pada operasi moneter yang dilakukan Bank Indonesia melalui pengelolaan likuiditas (liquidity management) di pasar uang untuk mencapai sasaran operasional kebijakan moneter. Sasaran operasional kebijakan moneter dicerminkan pada perkembangan suku bunga Pasar.

\section{Inflasi}

$$
\begin{aligned}
& \text { Menurut Mishkin (2008:13) } \\
& \text { menyatakan "inflasi sebagai } \\
& \text { kenaikan tingkat harga yang secara } \\
& \text { terus-menerus, mempengaruhi } \\
& \text { individu, pengusaha dan } \\
& \text { pemerintah". Menurut Kamus Bank } \\
& \text { Indonesia secara sederhana, inflasi } \\
& \text { diartikan sebagai meningkatnya } \\
& \text { harga-harga secara umum dan terus } \\
& \text { menerus. Kenaikan harga dari satu }
\end{aligned}
$$

atau dua barang saja tidak dapat disebut inflasi, kecuali bila kenaikan itu meluas (mengakibatkan kenaikan harga) pada barang lainnya. Kebalikan dari inflasi disebut deflasi. Kestabilan inflasi merupakan prasyarat bagi pertumbuhan ekonomi yang berkesinambungan yang pada akhirnya memberikan manfaat bagi peningkatan kesejahteraan masyarakat. Menurut Putong (2013:276) mendefinisikan "inflasi sebagai naiknya harga komoditi yang disebabkan oleh tidak sinkronnya antara program sistem pengadaan komoditi dengan tingkat pendapatan yang dimiliki oleh masyarakat di suatu negara tertentu. Inflasi tidak akan menjadi permasalahan ekonomi apabila diiringi oleh tersedianya komoditi yang diperlukan secara cukup dan diikuti dengan naiknya tingkat pendapatan yang lebih besar dari tingkat inflasi tersebut. Apabila biaya produksi untuk menghasilkan komoditi semakin tinggi, maka menyebabkan harga jual relatif tinggi. Sementara disisi lain tingkat pendapatan masyarakat relatif tetap tidak ada perubahan, maka inflasi akan menjadi masalah ekonomi bila berlangsung dalam waktu yang relatif lama dengan porsi berbanding terbalik antara tingkat inflasi terhadapat tingkat pendapatan.

Menurut Darmadji dan Fakhruddin (2006) dalam Andriyani (2016:52) mendefinisikan "inflasi sebagai suatu kondisi dimana harga barang-barang pada umumnya menjadi lebih tinggi dari sebelumnya". Inflasi yang berkaitan dengan pasar modal adalah investasi yang berasal dari sektor moneter. Hal ini karena inflasi berkaitan langsung dengan tingkat suku bunga dipasar. Jika inflasi meningkat, maka tingkat suku bunga juga akan meningkat. Jika suku bunga tidak ditingkatkan, maka tidak ada orang yang mau menabung uangnya di bank pada saat tingkat suku bunga sama dengan inflasi. Dampaknya 
adalah suku bunga akan meningkat sebagai upaya untuk menarik minat masyarakat menabung di bank.

Disisi lain, jumlah bank yang cukup banyak menyebabkan persaingan suku bunga antarbank menjadi ketat, sehingga bank akan berlomba-lomba memberikan suku bunga yang tinggi agar masyarakat menyimpan uang di bank tersebut, kondisi ini menyebabkan suku bunga tabungan akan menjadi lebih tinggi dari baisanya dan melebihi tingkat pengembalian hasil investasi di pasar modal. Akibatnya investasi di pasar modal menjadi tidak menarik lagi dan investor akan berduyunduyun mengalihkan dananya dari pasar modal ke tabungan karena memberikan tingkat pengembalian hasil yang lebih tinggi dan risiko yang lebih rendah.

Berdasarkan pendapat diatas dapat disimpulkan bahwa inflasi merupakan keadaan naiknya harga barang-barang dalam periode tertentu. Inflasi juga berpengaruh terhadap harga saham. Baik buruknya pengaruh inflasi tergantung pada besar kecilnya tingkat inflasi tersebut. Inflasi yang tinggi menurunkan harga saham perusahaan karena permintaan terhadap saham tersebut menurun.

\section{Nilai Tukar (Kurs) Rupiah}
Perdagangan internasional akan mendorong terjadinya pertukaran dua atau lebih mata uang berbeda. Transaksi ini akan menimbulkan permintaan dan penawaran terhadap suatu mata uang tertentu. Pada dasarnya, permintaan dan penawaran suatu mata uang tertentu akan mempengaruhi nilai tukar dari mata uang yang bersangkutan. Menurut Joesoef (2008) dalam Rohmanda dkk (2014:2) mendefisinisikan "kurs (exchange rate) adalah jumlah mata uang tertentu yang dapat ditukar terhadap satu unit mata uang lain".
Menurut Manurung (2009) dalam Ginting (2016:79)

mendefinisikan "nilai tukar adalah harga suatu mata uang dalam bentuk mata uang luar negeri".

Valuta asing (foreign exchange) adalah semua mata uang negara yang dapat digunakan untuk kegiatan perekonomian suatu negara dengan negara lain. Misalnya, mata uang Amerika Serikat berupa USD, mata uang Yen dari Jepang dan lain sebagainya. Setiap valuta asing tersebut mempunyai harga tertentu dalam mata uang suatu negara lain. Misalnya, USD dengan Rupiah, 1 USD $=\mathrm{Rp}$ 13.931, artinya harga 1 USD sama dengan $\mathrm{Rp}$ 13.931. Harga tersebut menggambarkan berapa banyak suatu mata uang harus dipertukarkan untuk memperoleh satu unit mata uang lain. Istilah lain rasio pertukaran tersebut adalah nilai tukar (exchange rate) atau kurs valuta asing.

Dari pengertian ahli diatas dapat disimpulkan bahwa nilai tukar atau kurs adalah harga suatu mata uang terhadap mata uang asing, seberapa mata uang domestik dihargai oleh mata uang asing. Nilai tukar juga merupakan salah satu harga yang terpenting dalam perekonomian terbuka mengingat pengaruh yang demikian besar bagi neraca transaksi berjalan maupun variabel-variabel makro ekonomi yang lain dan pada dasarnya merupakan jaringan kerja dari perbankan dan Lembaga keuangan dalam melayani masyarakat untuk membeli (permintaan) dan menjual (penawaran) valuta asing.

Naik turunnya nilai tukar mata uang pada waktu dilakukan transaksi valuta asing, dapat terjadi dengan berbagai cara yaitu resmi yang biasa dilakukan oleh pemerintah di suatu negara yang menganut sistem managed floating exchange rate atau bisa juga karena terjadinya tarik menarik antara penawaran dan permintaan di dalam pasar (market mechanism). 


\section{METODE}

Pada penelitian ini, metode yang digunakan adalah metode verifikatif dengan pendekatan kuantitatif. Menurut Sugiyono (2017:11) mendefinisikan "Metode verifikatif adalah suatu penelitian yang ditujukan untuk menguji teori, dan mencoba menghasilkan metode ilmiah yakni status hipotesis yang berupa kesimpulan, apakah suatu hipotesis diterima atau ditolak".

Pengambilan data Suku Bunga (BI Rate), Inflasi dan Nilai Tukar Rupiah diambil dari website resmi Bank Indonesia yaitu www.bi.go.id dan data Indeks Harga Saham Gabungan (IHSG) dari website resmi Bursa Efek Indonesia yaitu www.idx.co.id.

Populasi dalam penelitian ini adalah data-data yang termuat dalam website resmi Bank Indonesia (www.bi.go.id) dan Bursa Efek Indonesia (www.idx.co.id) yang terdiri dari 4 saham perusahaan telekomunikasi.
Tabel 1. Daftar Perusahaan Sektor Telekomunikasi

\begin{tabular}{|c|c|c|}
\hline No. & Nama Perusahaan & $\begin{array}{c}\text { Kode } \\
\text { Saham }\end{array}$ \\
\hline 1. & $\begin{array}{c}\text { PELEKOMUNIKASI } \\
\text { INDONESIA }\end{array}$ & TLKM \\
\hline 2. & PT INDOSAT & ISAT \\
\hline 3. & PT EXCEL AXCIATA & EXCL \\
\hline 4. & $\begin{array}{c}\text { PT SMARTFREN } \\
\text { TELECOM }\end{array}$ & FREN \\
\hline
\end{tabular}

\section{HASIL DAN PEMBAHASAN}

\section{Uji Hipotesis}

a. Uji Hipotesis Secara Uji Parsial ( Ujit)

Bahwa Uji-t (parsial) dilakukan untuk menentukan nilai koefisien regresi secara sendiri-sendiri terhadap variabel terikat (Y) apakah signifikan atau tidak. Ketentuan pengambilan keputusan uji parsial yaitu jika t hitung $>$ ttabel atau $\mathrm{t}$ hitung $<$ ttabel dan jika nilai prob. Pengujian ini menggunakan tingkat signifikansi $5 \%(\alpha=0,05)$,

Tabel 2. Hasil Uji Parsial (Uji-t)

\section{Coefficients $^{\mathrm{a}}$}

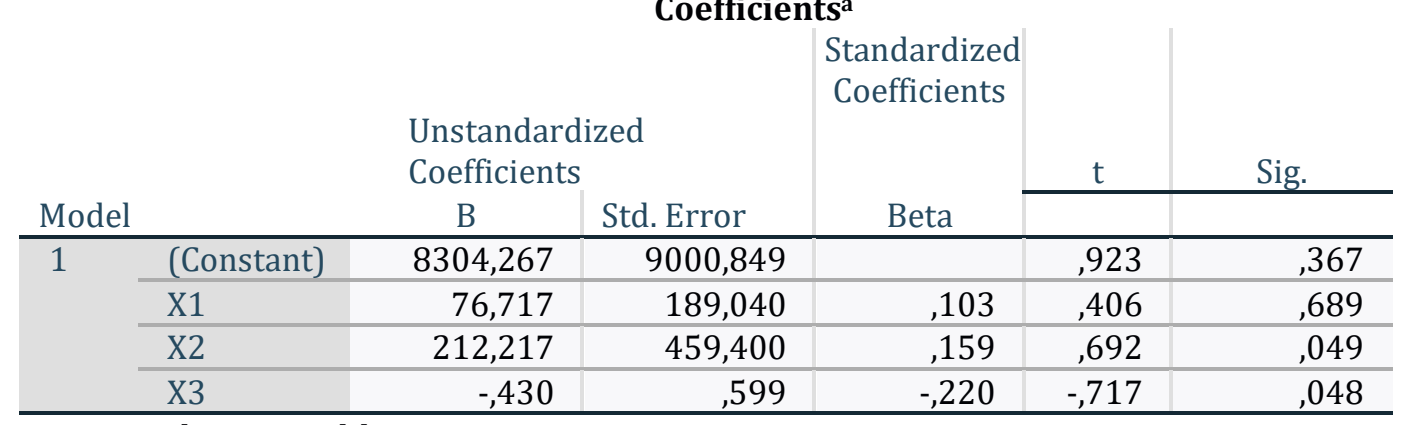

a. Dependent Variable: Y

Penjelasan dari tabel di atas adalah sebagai berikut:

\section{1) Pengaruh Suku Bunga terhadap} Harga Saham

Hasil pengujian analisis regresi data panel menunjukkan hasil t- hitung untuk variabel independen Suku Bunga adalah sebesar 0,406. Sementara nilai ttabel dengan $\alpha=5 \%$ dan $\mathrm{df}=(\mathrm{n}-\mathrm{k})=$ 20 , diperoleh nilai t-tabel adalah sebesar 0,687. yang berarti bahwa nilai t-hitung lebih kecil dari nilai ttabel $(0,406<0,687)$, kemudian jika dilihat dari nilai probabilitas yaitu sebesar 0.689 yang lebih besar dari 0,05 maka H0 diterima. Hal ini berarti bahwa Suku Bunga tidak memiliki pengaruh terhadap Harga Saham.

2) Pengaruh Inflasi terhadap Harga Saham

Dapat dilihat hasil pengujian dari tabel di atas dengan analisis 
regresi data panel yang menunjukkan bahwa t-hitung untuk variabel independen Inflasi adalah sebesar 0,692 , sementara dengan $\alpha$ $=5 \%$ dan $\mathrm{df}=(\mathrm{n}-\mathrm{k}), \mathrm{df}=20$ dimana nilai t-tabel adalah 0,687 yang berarti bahwa nilai t-hitung lebih besar dari nilai t-tabel $(0,692>$ 0,687 ), selain itu juga terlihat dari nilai probabilitas nya yaitu sebesar 0,049 yang lebih kecil dari 0,05 . Hal ini menyatakan bahwa Inflasi memiliki pengaruh yang signifikan terhadap harga Saham.

3) Pengaruh Nilai Tukar terhadap Harga Saham

Berdasarkan Tabel 4.22 menunjukkan hasil dari uji t dengan analisis regresi data panel yang menunjukkan hasil bahwa t-hitung untuk variabel independen nilai tukar adalah sebesar I- 0,717I (nilai absolut dari -0,717), sementara dengan $\alpha=5 \%$ dan $\mathrm{df}=(\mathrm{n}-\mathrm{k}), \mathrm{df}=20$ dimana nilai t-tabel adalah 0,687 yang berarti bahwa nilai t-hitung lebih besar dari nilai t-tabel $(0,717>$ 0,687 ), selain itu juga terlihat dari nilai signifikansinya yaitu sebesar 0,048 yang lebih kecil dari 0,05 . Hal ini menyatakan bahwa ni l a i t ukar memiliki pengaruh negatif yang signifikan terhadap harga Saham.

\section{b. Uji Hipotesis Secara Uji Simultan (} Uji-f )

Uji hipotesis secara simultan menggunakan uji F, tertera pada tabel berikut:

Tabel 3. Uji Simultan (Uji- F)

\begin{tabular}{|c|c|c|c|c|c|c|}
\hline \multirow[b]{2}{*}{ Mode] } & \multicolumn{6}{|c|}{ ANOVAa } \\
\hline & & Sum of Squares & Df & $\begin{array}{c}\text { Mean } \\
\text { Square }\end{array}$ & $\mathrm{F}$ & Sig. \\
\hline \multirow{3}{*}{1} & Regression & 2808300,625 & 3 & 936100,208 & $\begin{array}{c}11,6 \\
10\end{array}$ & $\begin{array}{c}, 03 \\
5^{b}\end{array}$ \\
\hline & Residual & 16131348,333 & 20 & 806567,417 & & \\
\hline & Total & 18939648,958 & 23 & & & \\
\hline
\end{tabular}

a. Dependent Variable: $Y$

b. Predictors: (Constant), X3, X1, X2

Sumber : ouput SPSS 28

Dengan hipotesis :

1) $\mathrm{HO}=$ Tidak terdapat pengaruh signifikan antara variabel Suku Bunga, Inflasi dan Nilai Tukar secara simultan terhadap Harga Saham

2) $\mathrm{H} 1$ = Terdapat pengaruh signifikan antara variabel Suku Bunga, Inflasi dan Nilai Tukar secara simultan terhadap harga saham

Berdasarkan hasil output SPSS 28 di atas, nilai $F$ hitung yaitu sebesar 11,61 sementara $F_{\text {tabel }}$ dengan tingkat $\alpha$ $=5 \%$ adalah sebesar 3,13. Dengan demikian $\mathrm{F}$ hitung $>\mathrm{F}$ tabel $(11,61>$ $3,13)$, kemudian juga terlihat dari nilai probabilitas yaitu sebesar 0,035 yang lebih kecil dari tingkat signifikansi sebesar 0,05 sehingga $\mathrm{H}_{0}$ ditolak. Hal ini menunjukkan bahwa variabel Suku

bunga, inflasi dan nilai tukar secara bersama-sama (simultan) mempunyai pengaruh yang signifikan terhadap harga saham, sehingga model regresi dapat digunakan untuk memprediksi variabel dependen.

\section{c. Koefisien Determinasi (Adjusted R- Square)}

Koefisien determinasi (Adjusted R-Square) pada intinya adalah untuk mengukur seberapa jauh kemampuan model dalam menerangkan variasi variabel dependennya. Nilai adjusted R-square yang mendekati satu berarti kemampuan variabel-variabel independen memberikan hampir semua informasi yang dibutuhkan untuk memprediksi variasi dependen. 
Tabel 4. Hasil Koefisien Determinasi (Adjusted R-Square)

\section{Model Summaryb}

\begin{tabular}{|c|c|c|c|c|c|}
\hline \multicolumn{6}{|c|}{ Model summary } \\
\hline $\begin{array}{c}\text { Mode } \\
1\end{array}$ & $\mathrm{R}$ & $\begin{array}{c}\mathrm{R} \\
\text { Square }\end{array}$ & $\begin{array}{c}\text { Adjuste } \\
\text { d R } \\
\text { Squar } \\
\text { e }\end{array}$ & $\begin{array}{c}\text { Std. Error of } \\
\text { the } \\
\text { Estimate }\end{array}$ & $\begin{array}{l}\text { Durbin } \\
\text { Watson }\end{array}$ \\
\hline 1 & ,673a & 453 & ,205 & 898,09098 & 1,700 \\
\hline
\end{tabular}

a. Predictors: (Constant), X3, X1, X2

b. Dependent Variable: $Y$

Sumber : ouput SPSS 28 (2021)

Berdasarkan tabel nilai adjusted $R$-Square Sebesar 0,205 maka variabel indepeden yaitu harga saham dapat dijelaskan sebesar $20,5 \%$ terhadap variabel dependen yaitu Suku bunga, inflasi dan nilai tukar Sedangkan sisanya 79,5\% dapat dijelaskan di luar model.

\section{Pembahasan Hasil Penelitian}

Analisis regresi yang telah dilakukan bertujuan untuk mengetahui hubungan yang dapat diukur dari return on asset,return on equity dan debt to equity ratio. Berikut ini tabel yang merangkum hubungan yang terjadi pada variabel independen terhadap harga saham

Tabel 5. Hubungan Variabel Indepeden Terhadap Harga Saham

\begin{tabular}{|c|c|c|}
\hline Variabel & $\begin{array}{c}\text { Hubungan Yang } \\
\text { Ditemukan }\end{array}$ & Signifikasi \\
\hline Suku Bunga & $\begin{array}{c}\text { Tidak } \\
\text { Berpengaruh }\end{array}$ & - \\
\hline Inflasi & Berpengaruh + & $\begin{array}{c}\text { Kurang } \\
\text { Signifikan }\end{array}$ \\
\hline Nilai Tukar & Berpengaruh - & Signifikan \\
\hline
\end{tabular}

Sumber : data yang diolah (2021)

\section{a. Pengaruh Suku Bunga Terhadap} Harga Saham

Hasil t-hitung untuk variabel independen adalah sebesar 0,406 sementara nilai t-tabel dengan $\alpha=5 \%$ dan $\mathrm{df}=(\mathrm{n}-\mathrm{k}), \mathrm{df}=21$ dimana nilai $\mathrm{t}$ tabel adalah sebesar 0,648. yang berarti bahwa nilai t-hitung lebih kecil dari nilai t-tabel $(0,406<0,648)$, kemudian jika dilihat dari nilai signifikansinya yaitu sebesar 0,689 yang lebih besar dari 0,05 maka H0 diterima, artinya secara parsial Suku Bunga tidak berpengaruh terhadap variabel dependen yaitu harga saham. Hal ini

sesuai dengan hasil penelitian Rusqiati \& Kangtono (2018) yang menyebutkan bahwa Suku Bunga tidak berpengaruh terhadap Harga Saham

b. Pengaruh Inflasi Terhadap Harga Saham

Dapat dilihat hasil pengujian dari tabel di atas dengan analisis regresi data panel yang menunjukkan bahwa thitung untuk variabel independen Inflasi adalah sebesar 0,692, sementara dengan $\alpha=5 \%$ dan $\mathrm{df}=(\mathrm{n}-\mathrm{k}), \mathrm{df}=19$ dimana nilai t-tabel adalah 0,687 yang berarti bahwa nilai t- hitung lebih besar dari nilai t-tabel $(0,692>0,687)$, selain itu juga terlihat dari nilai signifikansinya yaitu sebesar 0,049 yang hampir sama dengan 0,05. Sehingga dapat disimpulkan Ho ditolak dan H2 diterima artinya secara parsial variable independent Inflasi bepengaruh kurang signifikan terhadap variabel dependen yaitu Harga Saham. Hal ini sesuai dengan hasil penelitian Penelitian ini membuktikan bahwa inflasi berpengaruh positif dan kurang signifikan terhadap harga saham di Perusahaan Telekomunikasi periode 2015 - 2020. Hasil penelitian ini memiliki kesamaan dengan beberapa penelitian, diantaranya Witjaksono (2010), Chabachib dan Witjaksono (2011), Sunarjanto (2012), Riantani dan Tambunan (2013) yang berpendapat bahwa inflasi berpengaruh positif terhadap harga saham.

c. Pengaruh Nilai Tukar Terhadap Harga Saham

Menunjukkan hasil dari uji $\mathrm{t}$ dengan analisis regresi data panel yang menunjukkan hasil bahwa t-hitung untuk variabel independen Nilai Tukar adalah sebesar - 0,717, sementara 
dengan $\alpha=5 \%$ dan $\mathrm{df}=(\mathrm{n}-\mathrm{k}), \mathrm{df}=20$ dimana nilai t-tabel adalah 0,687 yang berarti bahwa nilai t-hitung lebih besar dari nilai t-tabel $(0,717>0,687)$, selain itu juga terlihat dari nilai signifikansi sebesar 0,04 yang lebih kecil dari 0,05. Sehingga dapat disimpulkan Ho ditolak dan HA diterima, artinya secara parsial bepengaruh yang signifikan dari variabel independen Nilai Tukar Ratio terhadap variabel dependen yaitu harga saham. Bila nilai tukar USD naik, artinya harga mata uang per dollar Amerika mengalami kenaikan. Hal ini menyebabkan ketidakstabilan ekonomi menyangkut kegiatan import, perdagangan dan hutang luar negeri, yaitu bila cadangan devisa negara kurang mampu untuk mengimbangi kebutuhan valuta asing tsb. Adanya kondisi ketidakstabilan ekonomi tsb, menyebabkan investor menunggu untuk melakukan investasi saham. Turunnya minat beli para investor dalam membeli saham, menyebabkan turun pula harga saham.

d. Pengaruh Suku Bunga, Inflasi, dan Nilai Tukar Terhadap Harga Saham

Pada analisis data panel pengolahan SPSS 28 nilai Fhitung yaitu sebesar 11,610 sementara $F$ tabel dengan tingkat $\alpha=5 \%$ adalah sebesar 3,13. Dengan demikian $F$ hitung $>F$ tabel $(11,610>3,49)$, kemudian juga terlihat dari nilai signifikansinya sebesar 0,035 yang lebih kecil dari tingkat signifikansi sebesar 0,05 sehingga H0 ditolak. Hal ini menunjukkan bahwa variabel Suku Bunga, Inflasi, dan Nilai Tukar secara bersama-sama (simultan) mempunyai pengaruh yang signifikan terhadap harga saham, dengan persamaan regresinya : $\mathrm{Y}=8304+76,7 \mathrm{X}_{1}+212,2 \mathrm{X}_{2}$ - $0,43 \quad X_{3 .,}$ dan menjelaskan pengaruhnya sebesar 20,5\%, sedangkan 79,5\% dipengaruhi oleh faktor lain.

\section{PENUTUP}

\section{Kesimpulan}

Dari hasil pengolahan data penelitian ini disimpulkan bahwa :

1. Tidak terdapat pengaruh antara Suku bunga dengan harga saham perusahaan telekomunikasi yang terdaftar di Bursa Efek Indonesia periode tahun 2015 - 2020.

2. Terdapat pengaruh positif signifikan antara Inflasi dengan Harga Saham Perusahaan Telekomunikasi yang terdaftar di Bursa Efek Indonesia periode tahun 2015 - 2020

3. Terdapat pengaruh negatif signifikan antara Nilai Tukar dengan Harga Saham Perusahaan Telekomunikasi yag terdaftar di Bursa Efek Indonesia Periode 2015 2020

4. Terdapat pengaruh signifikan antara Suku Bunga, Inflasi dan Nilai Tukar secara simultan dengan Harga Saham Perusahaan Telekomunikasi yang terdaftar di Bursa Efek Indonesia periode tahun 2015 - 2020

\section{Saran}

Untuk penelitian selanjutnya, sebaiknya dilakukan juga penelitian pengaruh fundamental ekonomi dan perusahaan terhadap harga Saham Telekomunikasi yang terdaftar di Bursa Efek Indonesia dengan periode yang lebih up to date.

\section{DAFTAR PUSTAKA}

Darmadji, Tjiptono dan Fakhruddin. (2012). Pasar Modal di Indonesia (Edisi 3). Jakarta: Salemba Empat.

Fahmi, dan Hadi. (2011). Teori Portofolio dan Analisis Investasi (Edisi 2), Bandung: Alfabeta.

Fahmi, Irham. (2013). Rahasia Saham dan Obligasi (Cetakan 1). Bandung: Alfabeta

Ghozali, Imam. (2013). Aplikasi Analisis Multivariate dengan Program IBM SPSS 21 Update PLS Regresi. Semarang: Badan Penerbit Universitas Diponegoro.

Hartono. (2017). Konsep Analisa Laporan Keuangan dengan Pendekatan Rasio dan SPSS. Yogyakarta: Deepublish.

Hasibuan, Malayu P. (2011). Manajemen Sumber Daya Manusia. Jakarta: PT Bumi Aksara.

Joesoef, J.R. (2008). Pasar Uang dan Pasar Valuta Asing. Jakarta: Salemba Empat. Jogiyanto, Hartono. (2010). Teori Portofolio dan Analisis Investasi (Edisi 7).Yogyakarta: BPFE.

Jogiyanto, Hartono. (2013). Teori Portofolio 
dan Analisis Investasi (Edisi 8), Yogyakarta: BPFE.

Kasmir. (2015). Manajemen Perbankan (Edisi Revisi). Jakarta: Raja Grafindo Persada.

Lutfi, A. M., et al. (2021). Pengaruh Capital Adequacy Ratio Dan Bopo Ratio Terhadap Return On Asset Pada Pt. Bank Muamalat Indonesia, Tbk Periode 2010-2019. Jurnal Ekonomi Efektif, 3(3), 420-428.

Madura, Jeff dan Roland Fox. (2011). International Financial Management, Boston: Cengage Learning.

Martalena, dan Maya Malinda. (2010). Pengantar Pasar Modal (Edisi 1), Yogyakarta: Andi.

Martono, dan Agus Harjito. (2011). Manajemen Keuangan (Edisi 2 Cetakan Pertama). Yogyakarta: Ekonisia.

Nababan, D., Putra, IGS., (2018). Analysis contribution and effectiveness of local taxes toward original regional income at Bandung City. International Journal of Engineering and Technology (UAE). 204-207.

Nitisemito, Alex S. (2013). Manajemen Personalia. Jakarta: Ghalia Indonesia. Nopirin. (2012). Pengantar Ilmu Ekonomi Mikro dan Makro. Yogyakarta: BPFE. Putong, Iskandar. (2013). Pengantar Mikro dan Makro (Edisi 5). Jakarta: Mitra Wacana Media.
Latumaerissa, Julius R. (2011). Bank dan Lembaga Keuangan Lain. Jakarta: Salemba Empat.

Noryani, Y. B. G., et al. (2020). Did ISO 45001, ISO 22000, ISO 14001 and ISO 9001 Influence Financial Performance? Evidence from Indonesian Industries. PalArch's Journal of Archaeology of Egypt/Egyptology, 17(7), 6930-6950.

Sadono, Sukirno. (2011). Makro Ekonomi Teori Pengantar. Jakarta: PT. Raajgrafindo Persada.

Solihin, Ismail. (2015). Corporate Social Responsibility From Charity To Sustainability. Jakarta: Salemba Empat.

Sugiyono. (2017). Metode Penelitian Kuantitatif, Kualitatif dan R\&D. Bandung: Alfabeta.

Sunariyah. (2013). Pengantar Pengetahuan Pasar Modal (Edisi 6). Yogyakarta: UPP STIM YKPN.

Supardi. (2013). Aplikasi Statistika dalam Penelitian. Jakarta: Grafindo Tandelilin, Eduardus. (2017). Pasar Manajemen Portofolio dan Investasi, Yogyakarta: Kanisius.

Weston, J. Fred dan Thomas E. (2010). Manajemen Keuangan (Edisi 9 Jilid 2) Penerjemah Kirbrandoko, A Jaka Wasana M dan Supranoto Dipokusumo. 